\title{
ANALISA PERILAKU PERAWAT DALAM PENERAPAN MANAJEMEN K3 DI RUMAH SAKIT
}

\section{SELLY FEBI MARGARETHA PANGGABEAN}

\author{
sellyfebi2601@gmail.com
}

\section{LATAR BELAKANG}

Rumah sakit merupakan institusi pelayanan kesehatan yang kompleks, padat profesi dan padat moral. Pelayanan rumah sakit menyangkut berbagai fungsi pelayanan kesehatan, pendidikan, penelitian dan juga mencakup berbagai tindakan maupun disiplin medis. Rumah sakit adalah tempat kerja yang memiliki potensi terhadap terjadinya kecelakaan kerja. Bahan mudah terbakar, gas medik, radiasi pengion, dan bahan kimia merupakan potensi bahaya yang memiliki resiko kecelakaan kerja. Oleh karena itu rumah sakit membutuhkan perhatian khusus terhadap keselamatan dan kesehatan khususnya pada perawat, staf dan umum (Sadaghiani, 2001 dalam Omrani dkk.,2015). Faktor yang menjadi kunci keberhasilan Rumah Sakit yaitu dalam menyediakan jasa pengobatan sangat ditentukan oleh kemampuan, kualitas kerja, atau tim medis yang menangani pasien dan kinerja mereka sendiri. Sedangkan salah satu faktor yang dapat mempengaruhi kinerja yaitu dalam melakukan penerapan K3 di rumah sakit.

Keselamatan dan kesehatan kerja (K3) merupakan salah satu isu penting di dunia kerja saat ini. Keselamatan dan kesehatan kerja di rumah sakit adalah segala bentuk upaya terpadu seluruh pekerja rumah sakit, pasien, pengunjung atau pengantar orang sakit untuk menciptakan lingkungan kerja dan tempat kerja rumah sakit yang sehat, aman, dan nyaman baik bagi pekerja rumah sakit, pasien, pengunjung, maupun masyarakat yang terdapat dalam lingkungan rumah sakit. Salah satu faktor keselamatan dan kesehatan kerja di rumah sakit yaitu sikap atau perilaku sangat berpengaruh pada keselamatan dan kesehatan kerja bagi perawat di rumah sakit.

Permasalahan kecelakaan kerja, menjadi salah satu masalah urgent di lingkungan rumah sakit. Hal ini diakibatkan karena rumah sakit merupakan suatu unit pelayanan kesehatan yang 
memberikan pelayanan pada semua bidang dan jenis penyakit. Oleh sebab itu rumah sakit dituntut untuk dapat menyediakan dan menerapkan suatu upaya agar semua sumber daya manusia yang ada di rumah sakit dapat terlindungi, baik dari penyakit maupun kecelakaan akibat kerja (Ivana, Widjasena \& Jayanti, 2014). Pemerintah melakukan berbagai upaya untuk mengatasi kecelakaan kerja di rumah sakit, salah satunya dengan dikeluarkannya UndangUndang Nomor 23 Tahun 1992 dan Undang-Undang Nomor 36 Tahun 2009 tentang penerapan Kesehatan dan Keselamatan Kerja di rumah sakit (Kepmenkes RI, 2010, p.8). Adapun upaya untuk mengendalikan, meminimalisasi dan bila mungkin meniadakannya, oleh karena itu K3RS perlu dikelola dengan baik. Sistem Manajemen Kesehatan dan Keselamatan Kerja merupakan sesuatu yang baru dan menjadi sasaran penilaian akreditasi rumah sakit. Menurut kajian (literature review) yang telah dianalisis, didapati hasil wawancara dengan petugas rumah sakit, baik perawat maupun petugas lain dimana sering terjadi kecelakaan kerja dirumah sakit seperti; tertusuk jarum, cedera, tergelincir pada saat berjalan namun kejadian tersebut tidak terdokumentasi dengan baik karena belum ada petugas K3 yang menangani hal tersebut. Menurut kajian (literature review) yang telah dianalisis, hasil penelitian Demak (2013) mengenai penyebab perilaku aman bekerja pada perawat di Rumah Sakit Islam Asshobirin Tangerang Selatan menyatakan bahwa bentuk perilaku tidak aman pada perawat yaitu tidak memakai sarung tangan ketika tindakan menyuntik dan memasang infus serta tidak menggunakan sepatu yang sesuai. Faktor yang menyebabkan perawat berperilaku tidak aman yaitu sikap negative perawat yang tidak disiplin dalam menggunakan Alat Pelindung Diri (APD) dan Standar Operasional Prosedur (SOP) yang berlaku di Rumah Sakit tersebut. Maka tujuan kajian ini yaitu untuk menganalisis dan mengetahui perilaku perawat dalam penerapan manajemen K3 di rumah sakit.

\section{METODE}

Dalam kajian ini, metode yang digunakan adalah metode kualitatif, maksudnya ialah dengan cara mengumpulkan sebanyak - banyaknya data untuk dibaca, dianalisis, dan disimpulkan. Yaitu dengan literature review ini dengan menganalisis yang berfokus tentang Analisa perilaku perawat dalam penerapan manajemen K3 dirumah sakit. Adapun tinjauan literature review yang digunakan yaitu kajian jurnal online, textbook, e- book, dan sumber literature review lainnya yang berkaitan dengan judul kajian tersebut. Selanjutnya data yang 
telah dibaca, kemudian dianalisis dan disimpulkan dapat digunakan sebagai bahan pengambilan keputusan dalam menanggulangi permasalahan. Dengan menggunakan jurnal dan referensi yang digunakan pada literature review ini dengan tahun terbit paling lama tahun 2012, dengan jumlah minimal 10 referensi literature.

\section{HASIL}

Berdasarkan hasil yang dapat dianalisis dari berbagai sumber (literature review) bahwa adanya hubungan sikap atau faktor perilaku perawat yang mempengaruhi penerapan manajemen K3 dirumah sakit. Adapun hasil dari ketiga jurnal yang telah dibaca, dianalisis, serta bisa disimpulkan terkait judul kajian diatas yaitu:

Jurnal Pertama yaitu, Perilaku Perawat Dalam Penerapan Manajemen Kesehatan Dan Keselamatan Kerja (K3) Di Aceh. Idea Nursing Journal Vol.VIII No.3 2017. Menurut hasil penelitian dari jurnal tersebut, Populasi yang digunakan dalam penelitian adalah seluruh perawat pelaksana Ruang Rawat Inap Rumah Sakit Umum Daerah dr. Zainoel Abidin Banda Aceh berjumlah 264 perawat. Sampel dalam penelitian jurnal ini merupakan bagian dari populasi target yang akan diteliti secara langsung yang berjumlah ( $\mathrm{n}=80$ ) perawat, yang didapati hasil dari faktor perilaku perawat terdiri dari faktor internal dan faktor eksternal. Hasil penelitian dari jurnal tersebut, dinyatakan kesimpulan bahwa sebagian besar perawat pelaksana memiliki perilaku yang baik dalam penerapan manajemen Kesehatan dan Keselamatan Kerja (K3) baik ditinjau dari faktor interal dengan $(f=42)$ dalam kategori baik (52.5\%) dan dengan $(f=38)$ dalam kategori kurang (47.5\%). Sedangkan pada faktor eksternal dengan $(f=47)$ dalam kategori baik $(58.8 \%)$ dan dengan $(f=33)$ dalam kategori kurang $(41.3 \%)$.

Jurnal Kedua yaitu, Faktor Psikologi Dan Perilaku Dengan Penerapan Manajemen Keselamatan Dan Kesehatan Kerja Rumah Sakit. Indonesian Journal of Public Health and Community Medicine Vol. 1, No. 3 Juli 2020. Menurut hasil penelitian jurnal tersebut, didapati hasil dari penerapan K3RS yang dipengaruhi oleh faktor hubungan keyakinan, persepsi, pengetahuan, sikap, serta tindakan. Adapun kesimpulan faktor- faktor hubungan dari hasil penelitian jurnal tersebut, diantaranya: 


\section{Keyakinan}

Dari faktor hubungan keyakinan, menunjukkan bahwa keyakinan dari responden tentang penerapan K3 rumah sakit paling banyak dalam kategori setuju, yaitu 34 responden $(56.7 \%)$ dan sisanya adalah responden dalam kategori yang tidak setuju sebanyak 26 responden (43.3\%). Berdasarkan hasil uji chi square, membuktikan terdapat hubungan yang bermakna antara keyakinan dengan penerapan K3RS di RSUD Pobundayan Kota Kotamobagu, yang memperoleh nilai $p=0,031$.

\section{Persepsi}

Hubungan dari faktor ini, menunjukkan bahwa persepsi dari responden tentang penerapan K3, didapati hasil dalam kategori tidak setuju yaitu 26 responden (43.3\%). Sedangkan dalam kategori setuju didapati sebanyak 34 responden (56.7\%). Berdasarkan hasil uji chi square, hubungan persepsi penerapan K3RS di RSUD Pobundayan Kota Kotamobagu diperoleh nilai $p=0,007$.

3. Pengetahuan

Hasil analisis data, pada faktor hubungan pengetahuan menunjukkan bahwa pengetahuan dari responden tentang penerapan $\mathrm{K} 3$, didapati hasil dalam kategori tidak tahu yaitu 29 responden (48.3\%), sedangkan hasil dalam kategori tahu didapati 31 responden $(51.7 \%)$. Hasil dari data penelitian ini membuktikan bahwa terdapat hubungan yang bermakna antara pengetahuan dengan penerapan K3RS di RSUD Pobundayan Kota Kotamobagu, yang memperoleh nilai $p=0,039$.

4. Sikap

Hasil pengolahan dan analisis data, hubungan sikap tentang penerapan $\mathrm{K} 3$, didapati hasil dalam kategori tidak setuju yaitu 29 responden (48.3\%), sedangkan dalam kategori setuju didapati 31 respoden (51.7\%). Hasil dari data penelitian ini membuktikan bahwa terdapat hubungan yang bermakna antara sikap responden dengan penerapan K3RS di RSUD Pobundayan Kota Kotamobagu, yang memperoleh nilai $p=0,039$.

5. Tindakan

Hasil pengolahan dan analisis data, hubungan tindakan tentang penerapan $\mathrm{K} 3$, didapati hasil dalam kategori tidak melakukan yaitu 26 responden (43.3\%), sedangkan dalam kategori melakukan didapati 34 responden. (56.7\%). Hasil dari data 
penelitian ini membuktikan bahwa terdapat hubungan yang bermakna antara tindakan dengan penerapan K3RS di RSUD Pobundayan Kota Kotamobagu, yang memperoleh nilai $p=0,007$.

Jurnal Ketiga yaitu, Hubungan Pengetahuan Dan Sikap Dengan Penerapan Kesehatan Dan Keselamatan Kerja (K3) Pada Perawat Di Rumah Sakit Bhayangkara TK III Manado. Jurnal KESMAS, Vol.8, No.7, November 2019. Menurut hasil penelitian jurnal tersebut, didapati pada tabel ke 12 tentang (Hubungan sikap dengan penerapan K3 pada perawat di rumah sakit Bhayangkara TK III Manado), menunjukkan bahwa sikap baik dengan penerapan K3 baik berjumlah 62 responden $(55,9 \%)$ dan sikap kurang baik dengan penerapan baik berjumlah 30 responden $(27,0 \%)$ sedangkan penerapan K3 kurang baik dengan sikap baik berjumlah 13 responden $(11,7 \%)$ dan penerapan K3 kurang baik dengan sikap kurang baik berjumlah 6 responden (5,4\%). Berdasarkan Hasil uji chi-square diperoleh hasil probabilitas $\leq 0,05$ yaitu 0,000 yang artinya terdapat hubungan antara sikap dengan penerapan K3 pada perawat di RS Bhayangkara Tk III Manado.

Maka hasil dari perbandingan ketiga jurnal tersebut dapat disimpulkan bahwa adanya hubungan yang saling keterkaitan antara hubungan sikap atau faktor perilaku perawat dalam penerapan manajemen K3 di rumah sakit, faktor hubungan keyakinan, persepsi, pengetahuan, sikap, serta tindakan yang sangat mempengaruhi perilaku perawat dalam menerapkan K3 didalam rumah sakit. Hal ini dikaitkan, agar perawat terus mengembangkan pengetahuan, sikap atau perilaku serta keterampilan di bidang manajemen khususnya K3, sehingga pelayanan yang diberikan dapat lebih optimal dan berkualitas tanpa melupakan tingkat kesehatan dan keselamatan bagi pemberi asuhan keperawatan.

\section{PEMBAHASAN}

\section{- Faktor Perilaku Perawat}

Berdasarkan hasil penelitian dari judul jurnal tersebut, Perilaku Perawat Dalam Penerapan Manajemen Kesehatan Dan Keselamatan Kerja (K3) Di Aceh. Idea Nursing Journal Vol.VIII No.3 2017, didapatkan penjelasan - penjelasan mengenai faktor perilaku perawat yang 
menunjukkan hasil bahwa sebagian besar perawat pelaksana memiliki perilaku yang baik dalam penerapan manajemen Kesehatan dan Keselamatan Kerja (K3) baik ditinjau dari faktor internal (52.5\%) maupun faktor eksternal (58.8\%). Berdasarkan dari asumsi peneliti ada berbagai faktor yang dapat mempengaruhi perilaku perawat ditinjau dari faktor internal berada pada kategori baik, diantaranya persepsi. Persepsi merupakan suatu proses pencarian informasi yang dilakukan oleh perawat sebelum melakukan suatu tindakan. Persepsi perawat tentang K3 menunjukkan bagaimana perawat mampu mencari tahu tentang pentingnya K3 baik melalui brosur, leaflet, SOP yang disediakan di ruangan maupun media informasi lainnya. Perawat juga dituntut untuk paham bagaimana cara pencegahan kecelakaan serta penanganan yang dapat dilakukan apabila kecelakaan terjadi. Pemahaman tersebut akan menimbulkan persepsi yang baik dalam diri perawat tentang $\mathrm{K} 3$ sehingga hal ini akan meningkatkan perilakunya dalam menjaga keselamatan. Selain persepsi, sikap juga mempengaruhi perilaku perawat ditinjau dari segi faktor internal (Notoadmodjo, 2010). Seorang perawat dalam melaksanakan manajemen K3 harus memiliki sikap yang sesuai dengan nilai-nilai kesehatan dimana seluruh nilai positif yang ada dalam dirinya menjadi pendorong perilaku sehat dan menjadi upaya dalam meningkatkan kesehatan dan keselamatan selama bekerja. Selain itu, Notoadmodjo (2010) menambahkan bahwa ada berbagai cara yang dapat dilakukan untuk meningkatkan persepsi, pengetahuan dan sikap perawat dalam menjaga kesehatan dan keselamatan selama bekerja, diantaranya dengan memberikan promosi kesehatan dan pelatihan tentang K3 sehingga hal ini diharapkan mampu merubah perilaku perawat menjadi lebih baik.

Dari data yang telah dianalisis, didapati peneliti berasumsi bahwa ada banyak juga faktor lain yang dapat menentukan perubahan perilaku perawat dari segi faktor eksternal, diantaranya pengalaman dalam masa kerja, fasilitas keamanan dan keselamatan, dan juga budaya organisasi yang sangat berpengaruh terhadap perilaku perawat dalam melaksanakan K3. Selanjutnya, berdasarkan hasil data yang telah dianalisis, didapati peneliti berasumsi bahwa perilaku perawat dalam penerapan manajemen Kesehatan dan Keselamatan Kerja (K3) ditinjau dari faktor internal dan juga eksternal berada pada kategori baik karena berbagai alasan, diantaranya; komite Kesehatan dan Keselamatan Kerja Rumah Sakit (K3RS) sudah melakukan fungsi manajeman K3RS dengan baik, seperti dilakukannya promosi kesehatan dan pelatihan tentang K3. 
- Hubungan Keyakinan, Persepsi, Pengetahuan, Sikap, dan Tindakan Terhadap Penerapan Manajemen K3RS

Berdasarkan hasil penelitian dari judul jurnal tersebut, Faktor Psikologi Dan Perilaku Dengan Penerapan Manajemen Keselamatan Dan Kesehatan Kerja Rumah Sakit. Indonesian Journal of Public Health and Community Medicine Vol. 1, No. 3 Juli 2020, didapatkan penjelasan- penjelasan mengenai hubungan yang mempengaruhi penerapan dalam manajemen K3RS yaitu :

\section{Hubungan Keyakinan terhadap Penerapan Manajemen K3RS}

Keyakinan diri dapat dikatakan sebagai kemampuan yang dirasakan untuk membentuk perilaku yang relevan pada tugas atau situasi yang khusus. Keyakinan diri dapat bersumber dari pengalaman akan kesuksesan, pengalaman individu lain, persuasi verbal, dan keadaan fisiologis individu (Smet, 1994 dalam Sumanto, 2014). Didapati hasil wawancara dengan responden, dimana sebagian besar responden setuju terhadap pelaksaan penerapan K3 rumah sakit, dimana rumah sakit harus berkomitmen untuk menjalankan atau menerapkan $\mathrm{K} 3$ rumah sakit secara kontinyu dan terus menerus. Kemudian ditemukan data yang telah dianalisis tentang penelitian yang sama yang dilakukan oleh Simanullang dan Yunikosta (2018) yang meneliti tentang hubungan persepsi keselamatan dan kesehatan kerja dengan perilaku K3 pada pekerja, membukitkan bahwa keyakinan akan pelaksanaan perilaku K3 yang kurang baik mempunyai risiko kecelekaan kerja sebesar 3 kali dibandingkan dengan keyakinan yang baik.

\section{Hubungan Persepsi terhadap Penerapan Manajemen K3RS}

Didapati hasil penelitian yang sejalan dengan penelitian yang dilakukan oleh Kerinci (2015) menunjukkan hasil bahwa persepsi keselamatan dan kesehatan kerja dengan perilaku K3 diperoleh nilai korelasi $(\mathrm{r})=0,405$ dan nilai $\mathrm{p}=$ 0,010, artinya hubungan persepsi keselamatan dan kesehatan kerja dengan perilaku K3 menunjukkan hubungan yang sedang dan berpola positif, artinya semakin baik persepsi keselamatan dan kesehatan kerja pekerja maka semakin baik pula perilaku K3 pekerja. Hasil uji statistik didapatkan ada hubungan yang signifikan antara persepsi keselamatan dan kesehatan kerja dengan 
perilaku K3. Adanya hubungan persepsi dengan penerapan K3 rumah sakit memberikan bukti bahwa peran kesadaran karyawan dalam menilai dan memberikan makna terhadap kondisi lingkungan kerja di RSUD Pobundayan Kota Kotamobagu terkait bahaya-bahaya yang dapat menyebabkan kecelakaan kerja sangat penting agar terwujudnya perilaku keselamatan yang semakin baik.

\section{Hubungan Pengetahuan terhadap Penerapan Manajemen K3RS}

Dari hasil analisis data, membuktikan bahwa terdapat hubungan yang bermakna antara pengetahuan dengan penerapan K3RS di RSUD Pobundayan Kota Kotamobagu, yang memperoleh nilai $p=0,039$. Hasil penelitian dalam jurnal ini didukung oleh penelitian yang dilaklukan oleh Pratama (2015) membuktikan bahwa terdapat hubungan yang bermakna antara tingkat pengetahuan denga penerapan manajemen keselamatan dan Kesehatan kerja, yang memperoleh nilai $p>0,05$. Penelitian yang sama dilakukan oleh Makayaino et al (2016) membuktikan bahwa terdapat hubungan yang bermakna antara pengetahuan dengan penerapan K3 rumah sakit.

Hasil wawancara yang didapati dengan responden, dimana menurut responden pengetahuan sesorang tentang manajemen K3 rumah sakit sangatlah penting, karena dengan pengetahuan yang tentang penerapan K3 rumah sakit akan meminimalis atau mengurangi penyakit akibat kerja atau kecelakaan akibat kerja.

\section{Hubungan Sikap terhadap Penerapan Manajemen K3RS}

Menurut Honda dkk (2014) dalam penelitian di Thailand, terdapat hubungan yang signifikan antara sikap perawat terhadap pencegahan cidera/ kecelakaan akibat benda tajam dan terjadinya cidera akibat benda tajam. Perawat yang memiliki sikap negative terhadap pencegahan cidera benda tajam hampir dua kali cenderung terkena cidera benda tajam dibandingkan dengan yang bersikap positif. Rumah sakit dapat mengurangi jumlah kejadian tertusuk benda tajam dengan meningkatkan sikap perawat dimana sikap sangat berhubungan dengan perilaku. Penelitian ini sesuai juga dengan penelitian 
yang dilakukan oleh Sandewa dan Adhiwijaya (2014) bahwa sikap ada hubungan dengan kejadian kecelakaan kerja.

\section{Hubungan Tindakan terhadap Penerapan Manajemen K3RS}

Hasil pengolahan serta analisis data pada jurnal tersebut, untuk tindakan responden membuktikan bahwa terdapat hubungan yang bermakna antara tindakan dengan penerapan K3RS di RSUD Pobundayan Kota Kotamobagu. Kemudian diperoleh data yang telah dianalisis, didapati tindakan yang dilalukan responden di rumah sakit RSUD Pobundayan Kota Kotamobagu, yaitu menunjang setiap program penerapan K3 di rumah sakit yaitu menggunakan APD pada setiap bekerja baik sebagai dokter, perawat, bidan dan tenaga kesehatan lainnya serta petugas kebersihan. Hal ini dilakukan untuk memperkecil risiko terjadinya kecelakaan akibat kerja dan penyakit akibat kerja.

\section{- Hubungan Sikap dengan Penerapan K3 pada Perawat di Rumah Sakit}

Berdasarkan hasil penelitian dari judul jurnal tersebut, Hubungan Pengetahuan Dan Sikap Dengan Penerapan Kesehatan Dan Keselamatan Kerja (K3) Pada Perawat Di Rumah Sakit Bhayangkara TK III Manado. Jurnal KESMAS, Vol.8, No.7, November 2019. Didapati penjelasan data yang telah dianalisis yaitu, Berdasarkan Hasil uji chisquare diperoleh hasil probabilitas $\leq 0,05$ yaitu 0,000 yang artinya terdapat hubungan antara sikap dengan penerapan K3 pada perawat yang artinya adanya hubungan saling keterkaitan atau bermakna antara sikap dengan penerapan kesehatan dan keselamatan kerja (K3) pada perawat di Rumah Sakit Bhayangkara TK III Manado.

\section{PENUTUP}

Peningkatan pemahaman K3 ditempat kerja dapat melalui pembandingan persepsi pekerja terhadap top manajemen, dimana sebenarnya standard dan aturan yang relevan akan membantu top manajemen untuk memberi arahan secara persuasif tentang faktor praktik kerja yang berisiko kecelakaan. Perilaku K3 akan tumbuh dari adanya umpan balik dari kejadian yang 
dianggap akan menimbulkan kecelakaan, sehingga dapat diketahui usaha antisipasi terhadap akibat yang akan datang, dan bermanfaat bagi pembelajaran organisasi dalam peningkatan K3.

Perilaku perawat dalam penerapan manajemen Kesehatan dan Keselamatan Kerja (K3) dapat ditinjau dari beberapa faktor diantaranya : faktor perilaku perawat yang meliputi; (faktor internal dan eksternal), hubungan dalam penerapan manajemen K3RS yang terkait dengan (keyakinan, persepsi, pengetahuan, sikap serta tindakan) dan juga hubungan sikap dengan penerapan K3 pada perawat di Rumah sakit. Adapun beberapa faktor - faktor diatas, memiliki keterkaitan yang sangat penting dalam menerapkan K3 di rumah sakit. Hal ini dikarenakan, agar petugas kesehatan, terutama perawat untuk dapat meningkatkan pengetahuan serta pelatihan keterampilannya sehingga dapat bekerja dengan lebih aman serta mengutamakan dalam melaksanakan keselamatan pasien sehingga tercapai adanya hubungan baik dalam penerapan perilaku perawat dalam melaksanakan manajemen K3 di rumah sakit. 


\section{DAFTAR PUSTAKA}

Anizar. (2012). Teknik Keselamatan dan Kesehatan Kerja di Industri. Yogyakarta: Graha Ilmu.

Ernawati, N., \& Nurlelawati, E. (2015). Faktor-Faktor Yang Berhubungan Dengan Pelaksanaan Penerapan K3 Pada Tenaga Kesehatan di RSIA Permata Saran Husada Periode Februari. Jurnal Akademi Keperawatan Husada KaryaJaya, 3(1).2017

Firawati. (2012). Pelaksanaan Program Keselamatan Pasien di RSUD Solok. Jurnal Kesehatan Masyarakat, Vol 6, No 2.

Ivana, A., Widjasena, B., \&Jayanti, S. (2014). Analisa Komitmen Rumah Sakit (RS) Terhadap Keselamatan Dan Kesehatan Kerja (K3) Pada RS Prima Medika Pemalang, Volume 2,Nomor 1, Hal 35-41.

Kumayas., P.E., Kawatu., P.A.T., Warouw., F. (2019). Hubungan Pengetahuan Dan Sikap Dengan Penerapan Kesehatan Dan Keselamatan Kerja (K3) Pada Perawat Di Rumah Sakit Bhayangkara TK III Manado. Jurnal KESMAS, Vol.8, No.7, November

Mantiri., E.Z.R.A., Pinontoan., O.R., \& Mandey., S. (2020). Faktor Psikologi Dan Perilaku Dengan Penerapan Manajemen Keselamatan Dan Kesehatan Kerja Rumah Sakit. Indonesian Journal of Public Health and Community Medicine Vol. 1, No. 3 Juli

Nazirah, R., \& Yuswardi. (2017). Perilaku Perawat Dalam Penerapan Manajemen Kesehatan Dan Keselamatan Kerja (K3) Di Aceh. Idea Nursing Journal Vol.VIII No.3.

Putri, S., Rahayu, E.P., \& Santoso. (2018) Pelaksanaan Keselamatan dan Kesehatan Kerja terhadap Kejadian Kecelakaan Kerja Perawat Rumah Sakit. Jurnal Endurance, 3 (2): 271 277.

Salawati, L., Taufik, H. N., Putra, A. (2014). Analisis Tindakan Keselamatan Dan Kesehatan Kerja Perawat Dalam Pengendalian Infeksi Nosokomial Di Ruang ICU RSUD dr. Zainoel Abidin Banda Aceh. Volume 14, Nomor 3.

Simamora, R. H. (2018). Buku ajar keselamatan pasien melalui timbang terima pasien berbasis komunikasi efektif: SBAR. Medan: USUpress. 
Simamora, R. H. (2019). Buku ajar pelaksanaan identifikasi pasien. Uwais Inspirasi Indonesia.

Tukatman., Sulistiawati., Purwaningsih., \& Nursalam. (2015). Analisis Keselamatan Dan Kesehatan Kerja Perawat Dalam Penanganan Pasien Di Rumah Sakit Benyamin Guluh Kabupaten Kolaka. Jurnal Ners Vol. 10 No. 2. 